\title{
IMPLEMENTASI METODE PEMBELAJARAN DAN GAYA KOGNITIF TERHADAP HASIL BELAJAR IPA KELAS V SISWA DI SDIT AL- JIHAD PEDES - KARAWANG
}

\author{
Yulistina Nur DS \\ PGSD Fakultas Keguruan dan Ilmu Pendidikan \\ Universitas Buana Perjuangan Karawang \\ yulistina.nur@ubpkarawang.ac.id
}

\begin{abstract}
The purpose of this research is to know the influence of learning method and cognitive style to students' science learning outcomes, especially in science subjects for elementary students. The research method used in this research is experiment with design treatment by level $2 \times 2$. The findings of this study indicate that: (1) there is a significant effect difference between the experimental learning method and the learning method of demonstration on the students' science learning outcomes. This can be proven from sig $0.000<0.05$ and $F_{0}=18.72$; (2) There is no significant effect between cognitive style on students' learning outcomes. This can be proven from sig. 0.104>0.05 and $F_{0} 2.737$; (3) There is no interaction effect between learning method and student's cognitive style on science learning outcomes. It is marked by the sig value. for learning method and cognitive style $0.937>0.05$ and $F_{0}=0.006$.
\end{abstract}

Key words: Method of learning, Experiment method, Science Learning Achievement

\begin{abstract}
Abstrak: Tujuan dari penelitian ini adalah untuk mengetahui pengaruh metode pembelajaran dan gaya kognitif terhadap hasil belajar IPA siswa, terutama pada mata pelajaran IPA untuk siswa SD. Metode penelitian yang digunakan dalam penelitian ini dalah eksperimen dengan menggunakan desain treatment by level $2 \times 2$. Temuan penelitian ini menunjukkan bahwa : (1) terdapat perbedaan pengaruh yang signifikan antara metode belajar eksperimen dengan metode belajar demontrasi terhadap hasil belajar IPA siswa. Hal ini dapat dibuktikan dari sig 0.000 $<0.05$ dan $\mathrm{F}_{0}=18.72$; (2) Tidak terdapat pengaruh yang signifikan antara gaya kognitif terhadap hasil belajar IPA siswa. Hal ini dapat dibuktikan dari sig. $0.104>$ 0.05 dan $\mathrm{F}_{0} 2.737$; (3) Tidak terdapat pengaruh interaksi antara metode belajar dan gaya kognitif siswa terhadap hasil belajar IPA. Hal ini ditandai dengan nilai sig. untuk metode belajar dan gaya kognitif $0.937>0.05$ dan $\mathrm{F}_{0} 0.006$.
\end{abstract}

Kata kunci: Metode Pmbelajaran, Gaya Kognitif, Hasil Belajar IPA 


\section{PENDAHULUAN}

Belajar dari negara-negara yang sudah maju, kita bisa mengambil pelajaran berharga betapa pendidikan merupakan hajat semua orang. Karena itu, maju dan mundurnya pendidikan merupakan tanggung jawab semua orang. Sebaliknya, di masyarakat kita pendidikan seolah hanya merupakan tanggung jawab guru atau sekolah dan pada tingkat negara pendidikan hanya menjadi tanggung jawab Kementerian Pendidikan. Jika demikian cara pandangnya, maka sampai kapan pun pendidikan kita tidak akan pernah bisa semaju sebagaimana di negara-negara yang telah mencapai prestasi puncak dalam pendidikan. Di tengah-tengah hiruk pikuk perpolitikan nasional kita saat ini dan tampaknya akan terus berlangsung lama perhatian pemerintah pun bisa tersedot pada hal-hal lain di luar tujuan pendidikan. Karena itu, wajar jika nilai atau prestasi kualitas pendidikan kita menurun dan sulit sekali bangkit dari peringkat 60- 70 .

Sebagai bangsa, kita juga ingin berdiri gagah di tengah bangsa-bangsa lain yang lebih maju, tidak melalui perang, melainkan melalui prestasi akademik lewat pendidikan. Memang sulit untuk mencapai prestasi itu, tetapi bukan tidak mungkin asal semua pihak sebagaimana disebutkan di muka bergandeng tangan membangun pendidikan secara serius.

Salah satu faktor yang cukup dominan adalah strategi dan model pembelajaran yang digunakan guru dalam kegiatan pembelajaran dan faktor dalam diri siswa yang meliputi gaya belajar dan kemandirian belajar. Guru adalah komponen yang sangat menentukan dalam implementasi suatu strategi pembelajaran. Tanpa guru, bagaimanapun bagus dan idealnya strategi, maka strategi itu tidak mungkin diaplikasikan. Layaknya seorang prajurit di medan pertempuran. Keberhasilan penerapan strategi berperang untuk menghancurkan musuh akan sangat bergantung pada kualitas prajurit itu sendiri. Demikian juga dengan guru, keberhasilan implementasi suatu strategi pembelajaran akan tergantung pada kepiawaian guru dalam menggunakan strategi, teknik dan taktik pembelajaran. Diyakini, setiap guru akan memiliki pengalaman, pengetahuan, kemampuan, gaya, dan bahkan pandangan yang berbeda dalam mengajar. Guru yang menganggap mengajar hanya sebatas menyampaikan materi pelajaran akan berbeda dengan guru yang 
menganggap mengajar adalah suatu proses pemberian bantuan kepada peserta didik.

Masing-masing perbedaan tersebut dapat mempengaruhi baik dalam penyusunan strategi atau implementasi pembelajaran. Guru dalam proses pembelajaran memegang peranan yang sangat penting. Peran guru apalagi untuk siswa pada usia pendidikan dasar, tak mungkin dapat digantikan oleh perangkat lain, seperti televisi, radio, komputer. Dan lain sebagainya. Sebab, siswa adalah organisme yang sedang berkembang yang memerlukan bimbingan dan bantuan orang dewasa. Oleh karena itu keberhasilan suatu proses pembelajaran sangat ditentukan oleh kualitas atau kemampuan guru. Kesan negatif yang diperoleh siswa dari lingkungan, baik lingkungan sekolah maupun di luar sekolah telah membentuk persepsi negatif siswa terhadap materi IPA. Informasi negatif ini, lama kelamaan dapat meruntuhkan keyakinan dan pada akhirnya mampu merubah kemandirian siswa dalam belajar. Selanjutnya, dalam diri siswa akan terbentuk pula sebuah kesimpulan bahwa bidang studi IPA bukanlah bidang studi yang menyenangkan untuk dipelajari melainkan akan tertanam dalam diri siswa bahwa IPA adalah bidang studi yang menjemukan dan perlu dihindarkan.

Proses yang berkelanjutan ini akan mempengaruhi pula gaya belajar siswa pada mata pelajaran IPA. Siswa dengan gaya belajar tertentu dapat menyebabkan kejenuhan dan merasa lelah. Akibatnya, siswa enggan untuk belajar mata pelajaran IPA, kondisi sebaliknya berlaku untuk siswa dengan gaya belajar yang menyukai tantangan dalam belajar. Mata pelajaran IPA sebagai pelajaran yang menarik dan penuh keunikan akan membuat siswa lebih percaya diri dan memiliki kemandirian yang kuat dalam belajar.

Pendidikan adalah usaha sadar dan terencana untuk mewujudkan suasana belajar dan proses belajar agar peserta didik secara aktif mengembangkan potensi dirinya untuk memiliki kekuatan spiritual keagamaan, pengendalian diri, kepribadian, kecerdasan, akhlak mulia, serta ketrampilan yang diperlukan dirinya, masyarakat, bangsa dan Negara. Berdasarkan pengamatan beberapa tahun belakangan ini, faktor-faktor yang mempengaruhi kemampuan anak yang kurang dalam IPA adalah faktor gaya belajar sehingga siswa membutuhkan arahan dan 
bimbingan untuk memotivasi anak dalam belajar. Dengan demikian hasil belajar akan dipengaruhi oleh gaya belajar dan kemandirian belajar. Oleh karena itu proses belajar yang aktif diharapkan dapat merangsang kemampuan berfikir siswa secara kreatif karena dapat memotivasi siswa dalam belajar sehingga menghasilkan proses belajar yang efektif dan dapat meningkatkan hasil belajar siswa.

Peran guru pada abad ke-21 diantaranya harus dapat menciptakan suatu pembelajaran yang berpotensi menciptakan suasana belajar mandiri, serta membawa kelas bagaikan magnet yang mampu memikat dan menarik siswa untuk belajar dalam suasana yang menyenangkan. Hal tersebut dapat dilakukan dengan mengintegrasikan teknologi dalam proses pembelajaran. Dengan memanfaatkan teknologi proses belajar untuk menguasai ilmu pengetahuan dan teknologi semakin cepat dan hemat waktu dan prosesnya akan semakin individual sesuai dengan kebutuhan setiap siswa tetapi sekaligus massal.

Dengan demikian bahwa usaha meningkatkan hasil belajar IPA dapat dilakukan dengan memperbaiki proses pembelajaran. Proses pembelajaran merupakan sekumpulan kegiatan dan serangkaian pengalaman yang dihadirkan oleh guru kepada peserta didiknya. Guru yang kompeten dan professional akan tanggap terhadap kemampuan siswa yang dimiliki. Dengan kemampuan tersebut, guru professional senantiasa memiliki strategi atau strategi dalam menyampaikan materi pelajaran kepada peserta didiknya.

\section{METODE PENELITIAN}

Penelitian ini menggunakan desain Treatment by Levels $2 \times 2$. Desain ini dipilih karena peneliti hanya melakukan perlakuan pada metode pembelajaran yang berbeda yaitu eksperimen sebagai kelas eksperimen 1 dan metode demontrasi sebagai kelas eksperimen 2. Sedangkan gaya kognitif bukanlah suatu perlakukan karena peneliti hanya mengelompokkan dan menyamakan siswa ke dalam dua kategori, yaitu siswa yang memiliki gaya kognitif field independent dan gaya kognitif field dependent. 


\section{Desain Penelitian}

\begin{tabular}{|c|c|c|}
\hline \multirow{2}{*}{$\begin{array}{c}\text { Level } \text { : Gaya Kognitif } \\
\text { (B) }\end{array}$} & \multicolumn{2}{|c|}{$\begin{array}{c}\text { Treatment } \text { : Penggunaan Metode } \\
\text { Pembelajaran }(\mathrm{A})\end{array}$} \\
\cline { 2 - 3 } & Eksperimen $\left(\mathrm{A}_{1}\right)$ & Demontrasi $\left(\mathrm{A}_{2}\right)$ \\
\hline Field Independent $\left(\mathrm{B}_{1}\right)$ & $\mathrm{A}_{1} \mathrm{~B}_{1}$ & $\mathrm{~A}_{2} \mathrm{~B}_{1}$ \\
\hline Field dependent $\left(\mathrm{B}_{2}\right)$ & $\mathrm{A}_{1} \mathrm{~B}_{2}$ & $\mathrm{~A}_{2} \mathrm{~B}_{2}$ \\
\hline
\end{tabular}

Populasi target disebut pula populasi teoritik, yaitu keseluruhan subjek penelitian secara teori yang banyaknya tidak terbilang. Oleh karena itu yang menjadi populasi target dari penelitian ini adalah seluruh siswa kelas V SDIT AlJihad Pedes Karawang.

Sesuai masalah yang diteliti populasi terjangkau dalam penelitian ini adalah siswa kelas V A yang berjumlah 38 dan kelas V B yang berjumlah 38 di SDIT AlJihad Pedes Karawang yang terdaftar pada tahun pelajaran 2017/ 2018.

Karena jumlah anggota sampel yang terbatas, maka dalam penelitian ini mengambil 60 siswa sebagai sampel penelitian. Dari 60 siswa tersebut dibagikan dalam 4 kelompok masing-masing 15 siswa. 15 siswa gaya kognitif field dependent dengan metode pembelajaran eksperimen, 15 siswa gaya kognitif field independent dengan metode pembelajaran eksperimen, 15 siswa dengan gaya kognitif field dependent dengan metode pembelajaran demontrasi, dan 15 siswa dengan gaya kognitif field independent dengan metode pembelajaran demontrasi. Teknik yang digunakan adalah teknik cluster random sampling.

Teknik pengambilan sampel dilakukan dengan menggunakan metode simple random sampling (Sugiyono, 2010: 64). Dikatakan simple karena pengambilan anggota sampel dari populasi dilakukan secara acak tanpa memperhatikan strata yang ada dalam populasi itu.

Instrumen hasil belajar IPA dengan menggunakan tes tertulis, perangkat tes yang digunakan untuk mengukur hasil belajar ini berbentuk tes objektif, yaitu bentuk tes pilihan ganda dengan empat alternatif jawaban dan instrumen gaya kognitif dengan menggunakan angket. Untuk pengujian normalitas data dilakukan dengan menggunakan Uji Liliefors dan uji homogenitas dengan Uji Barlett. Adapun 
teknik analisis data yang digunakan yaitu ANAVA dua jalur dan pengujian simple effect dengan Uji Tuckey.

Pengumpulan data tentang hasil belajar IPA siswa dengan pemberian tes evaluasi kepada siswa yang diuji. Pada pokok bahasan perubahan benda. Pengumpulan data tentang gaya kognitif siswa dilakukan dengan penyebaran angket kepada siswa kelas V sebagai sampel penelitian.

Teknik pengambilan data dalam bentuk pemberian metode pembelajaran yaitu pada kelompok eksperimen pertama diberikan pengajaran IPA pokok gaya magnet dengan menggunakan metode eksperimen, sedangkan kelompok eksperimen kedua diberikan pengajaran IPA pokok bahasan gaya magnet menggunakan metode demontrasi. Setelah pembelajaran materi pokok bahasan gaya magnet yaitu selama satu kali pertemuan pada masing-masing kelas, selanjutnya pada kedua kelas sampel ini diberikan tes hasil belajar IPA.

\section{HASIL DAN PEMBAHASAN}

Penelitian ini merupakan eksperimen dua faktor ialah faktor metode pembelajaran (A) dan faktor gaya kognitif (B), masing-masing faktor terdiri dari sub faktor yang disebut level. Untuk faktor metode pembelajaran ada dua level ialah pertama level eksperimen (A1) dan level kedua metode demontrasi (A2). Faktor kedua adalah gaya kognitif dengan dua level, pertama gaya kognitif Independent (B1), kedua gaya kognitif dependent (B2). Rangkuman data hasil penelitian sesuai dengan rancangan penelitian sebagaimana tabel di bawah ini.

\section{Descriptive Statistics}

Dependent Variable:Hasil Belajar IPA

\begin{tabular}{|ll|c|c|c|}
\hline Kelas & Gaya Kognitif & Mean & Std. Deviation & $\mathrm{N}$ \\
\hline Kelas Eksperimen & Gaya Kognitif Field Independent & 75.33 & 6.673 & 15 \\
& Gaya Kognitif Field Dependent & 71.67 & 8.591 & 15 \\
& Total & 73.50 & 7.785 & 30 \\
\hline Kelas Kontrol & Gaya Kognitif Field Independent & 66.00 & 7.838 & 15 \\
& Gaya Kognitif Field Dependent & 62.67 & 9.424 & 15 \\
& Total & 64.33 & 8.683 & 30 \\
\hline Total & Gaya Kognitif Field Independent & 70.67 & 8.584 & 30 \\
& Gaya Kognitif Field Dependent & 67.17 & 9.973 & 30 \\
& Total & 68.92 & 9.392 & 60 \\
\hline
\end{tabular}


Berdasarkan data ini menunjukkan bahwa berdasarkan tabel di atas untuk kelas eksperimen (A1) mempunyai rata-rata nilai 73.50 jauh lebih besar dibandingkan dengan kelas kontrol dengan nilai rata-rata hanya sebesar 64.33. Secara deskriptif menunjukkan bahwa kelas eksperimen dapat dinyatakan berhasil. Kemudian jika dilihat dari gaya kognitif menunjukkan bahwa untuk siswa dengan gaya kognitif field independent mempunyai nilai rata-rata 70.67 lebih tinggi dibandingkan dengan siswa dengan gaya kognitif field dependent yaitu 67.17.

Ada temuan pada analisis ini adalah untuk kelompok siswa dengan gaya kognitif field independent secara umum mempunyai nilai rata-rata IPA lebih tinggi dibandingkan dengan kelompok siswa dengan gaya kognitif field dependent .

Untuk menentukan apakah variabel normal atau tidak maka dilakukan uji normalitas dengan menggunakan uji Kolmogorov-Smirnov dengan SPSS 16. Dalam hal ini yang diuji adalah hipotesis $\mathrm{Nol}\left(\mathrm{H}_{0}\right)$. Untuk menolak $\mathrm{H}_{0}$ dilakukan dengan taraf signifikansi 0,05 atau membandingkan nilai signifikansi dengan berdasarkan kriteria berikut:

Uji Normalitas Data Penelitian

One-Sample Kolmogorov-Smirnov Test

\begin{tabular}{|ll|c|c|c|}
\hline & & Kelas & Gaya Kognitif & HasilBelajar IPA \\
\hline N & & 60 & 60 & 60 \\
Normal Parameters ${ }^{\mathrm{a}}$ & Mean & 1.50 & 1.50 & 68.92 \\
& Std. Deviation & .504 & .504 & 9.392 \\
Most Extreme Differences & Absolute & .339 & .339 & .164 \\
& Positive & .339 & .339 & .137 \\
& Negative & -.339 & -.339 & -.164 \\
Kolmogorov-Smirnov Z & & 2.628 & 2.628 & 1.273 \\
Asymp. Sig. (2-tailed) & & .000 & .000 & .078 \\
\hline a. Test distribution is Normal. & & &
\end{tabular}

Dari hasil perhitungan dengan SPSS 16 di atas, menunjukkan bahwa nilai uji statistik KS untuk hasil belajar IPA yaitu 1.273 dan Sig. $0.078>0.05$ yang berarti data hasil belajar berdistribusi normal.

Dalam analisis perbedaan selain harus memenuhi asumsi bahwa data berasal dari populasi berdistribusi normal, juga harus memenuhi asumsi homogenitas varians. Uji homogenitas bertujuan untuk mengetahui apakah varians berasal dari 
populasi yang bersifat homogen. Pengujian homogenitas data hasil belajar IPA siswa dilakukan dengan uji lavene pada taraf signifikansi 0.05. Untuk pengujian homogenitas diajukan hipotesis sebagai berikut:

$\mathrm{H}_{0} \quad$ : Data berasal dari populasi homogen

$\mathrm{H}_{1} \quad$ : Data berasal dari populasi yang tidak homogen

Dengan kriteria:

Jika nilai sig. (levene's test) $>0.05$; maka $\mathrm{H}_{0}$ diterima dan $\mathrm{H}_{1}$ ditolak Jika nilai sig. (levene's test) $<0.05$; maka $\mathrm{H}_{1}$ diterima dan $\mathrm{H}_{0}$ ditolak

Ringkasan Hasil Perhitungan Uji Homogenitas Hasil Belajar IPA Levene's Test of Equality of Error Variances ${ }^{a}$

Dependent Variable:HasilBelajar IPA

\begin{tabular}{|c|c|c|c|}
\hline$F$ & $d f 1$ & $\mathrm{df} 2$ & Sig. \\
\hline 428 & 3 & 56 & .733 \\
\hline
\end{tabular}

Tests the null hypothesis that the error variance of the dependent variable is equal across groups.

a. Design: Intercept $+A+B+A$ * $B$

Dari perhitungan data di atas, diperoleh nilai sig. $0.733>0.05$ dengan demikian $\mathrm{H}_{0}$ diterima dan $\mathrm{H}_{1}$ ditolak dan data berasal dari populasi yang homogen.

Setelah dilakukan uji normalitas dan homogenitas dan hasilnya menunjukkan bahwa sampel penelitian berasal dari populasi berdistribusi normal dan varians sampel homogen, maka pengujian hipotesis dengan menggunakan ANOVA dapat dilakukan. Analisis terhadap data hasil belajar siswa dilakukan dengan menggunakan ANOVA dua arah. 
Tests of Between-Subjects Effects

Dependent Variable:HasilBelajar IPA

\begin{tabular}{|l|r|r|r|r|r|}
\hline Source & $\begin{array}{c}\text { Type III Sum of } \\
\text { Squares }\end{array}$ & Df & Mean Square & \multicolumn{1}{c|}{ F } & \multicolumn{1}{c|}{ Sig. } \\
\hline Corrected Model & 1444.583 & 3 & 481.528 & 7.172 & .000 \\
Intercept & 284970.417 & 1 & 284970.417 & $4.244 \mathrm{E} 3$ & .000 \\
A (Metode Pembelajaran) & 1260.417 & 1 & 1260.417 & 18.772 & .000 \\
B (Gaya Kognitif) & 183.750 & 1 & 183.750 & 2.737 & .104 \\
A * B & .417 & 1 & .417 & .006 & .937 \\
Error & 3760.000 & 56 & 67.143 & & \\
Total & 290175.000 & 60 & & & \\
Corrected Total & 5204.583 & 59 & & & \\
\hline
\end{tabular}

a. $\mathrm{R}$ Squared $=.278$ (Adjusted R Squared $=.239$ )

Dari hasil analisis data di atas dapat diintepretasikan sebagai berikut:

1. Terdapat pengaruh metode pembelajaran terhadap hasil belajar IPA yang sangat signifikan. Hal ini ditandai dengan nilai sig. untuk metode belajar $0.000<0.05$ dengan demikian dapat disimpulkan terdapat pengaruh metode belajar terhadap hasil belajar IPA. Hal ini didukung oleh perolehan rerata skor hasil belajar IPA dengan metode eksperimen 71.00 yang lebih tinggi dari hasil belajar IPA dengan metode demontrasi 62.00. Fenomena ini menunjukkan hasil belajar IPA akan meningkat bila siswa diajar dengan metode eksperimen. Penggunaan metode eksperimen dapat meningkatkan hasil belajar IPA karena dengan penggunaan metode ini lebih mengaktifkan siswa selama pembelajaran berlangsung. Selain itu dengan metode pembelajaran eksperimen dapat memfasilitasi siswa dengan pengalaman sikap kepemimpinan dan membuat keputusan dalam kelompok, serta memberikan kesempatan pada siswa untuk berinteraksi dan belajar berasosiasi, berargumentasi dengan siswa lain yang berbeda latar belakangnya. Peranan guru dalam pembelajaran eksperimen adalah sebagai motivator, fasilitator dan konselor. Kegiatan dalam proses pembelajaran lebih berpusat pada siswa sehingga siswa dalam berkesempatan mengembangkan kreativitas dan potensi kognitif maupun sosialnya.

2. Tidak terdapat pengaruh gaya kognitif belajar terhadap hasil belajar IPA yang sangat signifikan. Hal ini ditandai dengan nilai sig. untuk gaya kognitif $0.104>$ 0.05 dan $\mathrm{F}_{0}$ 2,737 dengan demikian dapat disimpulkan tidak terdapat pengaruh 
gaya kognitif yang signifikan terhadap hasil belajar IPA. Dengan kata lain, tidak terdapat perbedaan hasil belajar siswa yang memiliki gaya kognitif field independent dengan siswa yang memiliki gaya kognitif field dependent.

Fenomena ini menunjukkan siswa yang memiliki gaya kognitif field independent menimbulkan dorongan yang kuat dari dalam diri untuk berkompetensi sehingga membuat siswa lebih percaya diri dalam menjawab soal, belajar lebih senang karena tidak ada unsur paksaan, kesadaran tinggi lebih besar dan merasa bertanggung jawab. Siswa yang memiliki gaya kognitif field independent sudah barang tentu hasil belajarnyapun akan meningkat sementara siswa yang memiliki gaya kognitif field dependent dalam kegiatan belajar sudah barang tentu hasil belajarnya akan menurun.

3. Tidak terdapat pengaruh interaksi antara metode belajar dan gaya kognitif siswa terhadap hasil belajar IPA. Hal ini ditandai dengan nilai sig. $0.937>0.05$ dan $\mathrm{F}_{0}$ 0.006. Dengan demikian $\mathrm{H}_{0}$ diterima dan $\mathrm{H}_{1}$ ditolak sehingga dapat disimpulkan tidak terdapat pengaruh interaksi antara metode belajar dan gaya kognitif siswa terhadap hasil belajar IPA.

Berdasarkan hasil ANOVA, terlihat bahwa interaksi yang terjadi antara metode pembelajaran dan gaya kognitif siswa pada pelajar IPA nerupakan interaksi yang tidak meyakinkan. Karena tidak adanya interaksi, maka tidak dilakukan analisis lanjutan untuk melihat simple effect diantara sub-sub faktor yang membangun interkasi tersebut. Berdasarkan uraian di atas maka dapat disimpulkan bahwa tidak terdapat pengaruh interaksi metode pembelajaran dan gaya kognitif terhadap hasil belajar IPA.

Metode belajar merupakan suatu patokan dalam menyusun kegiatan belajar siswa di sekolah. Sudah seharusnya seorang guru mempersiapkan rencana belajar, metode belajar yang digunakan dan instrumen yang sesuai dengan perencanaan. Namun pada kenyataannya dalam penelitian ini tidak ditemukan adanya pengaruh interaksi antara metode belajar dan gaya kognitif terhadap hasil belajar IPA. Hal ini mungkin terjadi bahwa dalam pemilihan sampel dan pelaksanaan eksperimen terjadi kesalahan atau terdapat variabel pengganggu yang tidak dikontrol oleh peneliti. 


\section{PENUTUP}

Berdasarkan dari hasil pengujian hipotesis penelitian dan analisis pengolahan data, maka dapat disimpulkan sebagai berikut:

1. Terdapat perbedaan pengaruh yang signifikan antara metode belajar eksperimen dengan metode belajar demontrasi terhadap hasil belajar IPA siswa. Hal ini dapat dibuktikan dari sig $0.000<0.05$ dan $\mathrm{F}_{0}=18.72$.

2. Tidak terdapat pengaruh yang signifikan antara gaya kognitif terhadap hasil belajar IPA siswa. Hal ini dapat dibuktikan dari sig. $0.104>0.05$ dan $\mathrm{F}_{0} 2.737$.

3. Tidak terdapat pengaruh interaksi antara metode belajar dan gaya kognitif siswa terhadap hasil belajar IPA. Hal ini ditandai dengan nilai sig. untuk metode belajar dan gaya kognitif $0.937>0.05$ dan $\mathrm{F}_{0} 0.006$.

\section{DAFTAR PUSTAKA}

Arikunto, Suharsimi. 2006. Prosedur Penelitian Suatu Pendekatan Praktik. Jakarta: Rineka Cipta.

Carin, Arthur. Dan Sund, Robert B. 1989. Teaching Science Through Discovery. Columbus: Merrill Publishing Company.

Chain, Shandra E. Dan Evans, Jack M. 1980. An Involvement Approach to Elementary Science Methods. Columbus: Merrill Publishing Company.

Depdikbud. 2005. IPA, Kurikulum dan Silabus IPA. Jakarta: Depdiknas. 2005. IPA, Strategi dan Strategi Pembelajaran IPA. Jakarta: Depdiknas.

Dimyati dan Mudjiono. 2009. Belajar dan Pembelajaran. Jakarta: PT Rineka Cipta Sabri, Ahmad. 2010. Strategi Belajar Mengajar. Jakarta: PT Ciputat Press.

Sagala, Syaiful. 2010. Konsep dan Makna Pembelajaran. Bandung: Alfabeta.

Samatowa, Usman. 2010. Pembelajaran IPA di Sekolah Dasar. Jakarta: Indeks.

Semiawan, Conny. 1999. Pendidikan Tinggi: Peningkatan Kemampuan Manusia Sepanjang Hayat Seoptimal Mungkin. Jakarta: Grasindo.

Sugiyono. 2007. Metode Penelitian Pendidikan Pendekatan Kuantitatif, Kualitatif, dan $R \& D$. Bandung: Alfabeta. 